DOI: https://doi.org/10.31933/dijms.v2i1

Received: 6 June 2020, Revised: 15 August 2020, Publish: 16 September 2020

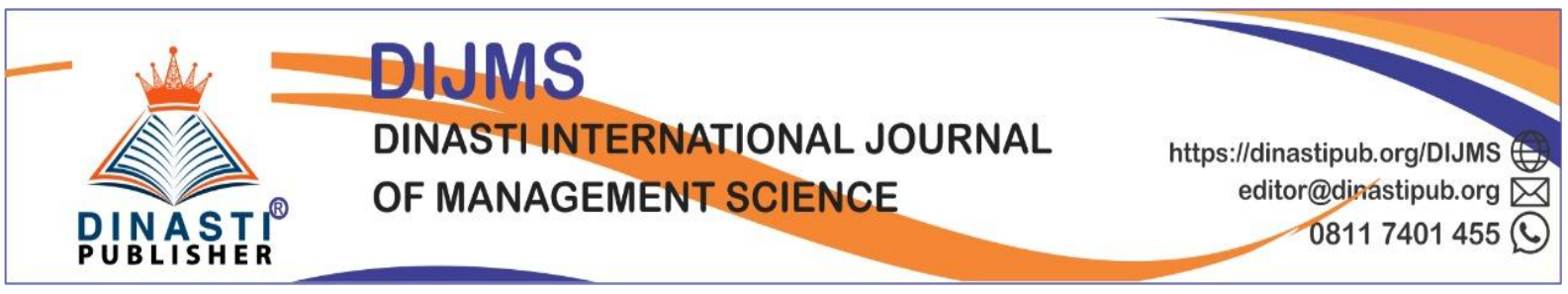

\title{
THE EFFECT OF COMPENSATION AND WORK ENVIRONMENT TO EMPLOYEE PERFORMANCE OF PT ASS
}

\section{Magito}

Faculty of Economics and Business Universitas Mercu Buana, Indonesia, magito@mercubuana.ac.id

\section{Corresponding Author: First Author}

\begin{abstract}
This study is to determine the effect of compensation and work environment on employee performance. The object of this research is PT ASS, located in Central Jakarta. The entire population numbered 43 people and the number of samples used as respondents in this study was 43 people, the way to distribute questionnaires was using the Simple Random Sampling technique. The research instrument used as a measuring instrument in the form of a questionnaire with a Likert scale. The results of the questionnaire answers are then processed using SPSS 23 Software, the data analysis used is statistical analysis in the form of multiple linear regression tests. The results of this study indicate partially compensation variables on employee performance and influence partially with work environment variables and influence on employee performance, this will be evidenced by the results of the partial significance test (t-test).
\end{abstract}

Keywords: Compensation, Work Environment, Employee Performance

\section{INTRODUCTION}

Human resources are one of the assets in a valuable company and is a very important cog to get good performance, in other words without good and competent human resources in a company, the company will be left behind by other companies. Employee performance is an important factor because the progress of an organization depends on its human resources. If performance increases, the success of achieving company goals is increasingly wide open and vice versa. Employees' performance sometimes increases and sometimes decreases. This needs to be considered, what should be done to anticipate this, what can affect employee performance in an organization.

In this study, PT ASS's turn over data in 2016 showed that there were seven people who decided to resign. According to information from the management of employees who resigned are competent employees, it means the company lost a number of workers. This will have an impact on the company's operations because new employees need time to process adaptation and adjustment. This is very important because it will have an impact on the cost, time, and continuity of the company's operations. Why did the employee resign? There are a number of factors that can be predicted, such as a less satisfactory compensation factor, a workload that is too heavy, or an uncomfortable working environment.

In order to achieve company goals, PT ASS has a strategy and one of them is recruiting competent new employees so that performance in the company remains stable. PT 
ASS employee turn over data for 2016 showed that there were 19 new employees. However, there are times when the strategy used, such as the addition of employees that aims to improve the quality of the company turns out to have an impact on the workspace becomes narrow if not immediately renovated for room expansion or can be relocated (moving offices). If the room is cramped, the room becomes less cool and less comfortable, this can have an impact on existing activities in the office and even can have an impact on employee performance results.

With the problems that occur, the authors conducted a pre-survey by distributing questionnaires of 15 employees at PT ASS. And the results of the pre-survey explain that respondents feel the salary provided is often not timely, the absence of overtime, this needs the attention of the company because it can have an impact on employee rights satisfaction and affect performance. Poor air circulation, good workspace arrangement, and lack of space can have an impact on the comfort of employees when doing activities. But employees keep trying to make a good contribution to the company.

The objectives to be achieved in this study are: To determine the effect of compensation on the performance of PT ASS employees and to determine the effect of the work environment on the performance of PT ASS employees. The contributions of this research are as follows: (1) this research is expected to be able to increase knowledge about the scope of human resources, especially regarding the work environment, financial compensation and employee performance. Or as reference material in the science of human resource management so that it can enrich and add insight; (2) this research is expected to be taken into consideration or developed further, especially those related to human resource management.

\section{LITERATURE REVIEW}

Human resource is an asset that is owned by the company to achieve goals or the ability to benefit from existing opportunities (Sunyoto, 2015). Human resource management in general to obtain the highest level of employee development, harmonious work relations among employees, and effective integration of human resources or efficiency and cooperation goals, is expected to increase work productivity (Sunyoto, 2015).

\section{Employee performance}

Employee performance is the performance achievement or work output (output) both quality and quantity achieved by the employees of a time period in carrying out their work duties in accordance with the responsibilities given to them (Mangkunegara, 2009). Furthermore, researchers will also put forward the definition of employee performance according to Rivai (2011), "saying that," performance is a real behavior displayed by everyone as work performance produced by employees in accordance with their role in the company. " Understanding of Performance according to Beach in (Umar, 2013), "Performance is a systematic assessment of individual employees regarding their work performance and potential for development."

The understanding of experts based on the description above can be concluded that with the results of work achieved by an employee in doing a job can be evaluated the level of employee performance, then employee performance must be determined by achieving targets over a period of time achieved and in line with organizational goals.

\section{Performance assessment}

The appraisal approach makes employees protect themselves against appraisal, and managers themselves are reluctant to use the term appraisal but prefer to use the term evaluation, where employees are involved in meetings: performance review and development 
(PR\&D) which are the approach is passive development. According to Hasibuan (2006), the notion of performance appraisal is, "the manager's activities to evaluate employee work performance behavior and establish further policies, and work performance appraisal is to assess real work results with quality and quantity standards produced by each employee."

According to Bernardin and Russel in Sutrisno (2010) in proposing six primary performance that can be used to measure performance, namely:

1) Quality. Is the degree to which the process or results of the implementation of activities close to perfection or near the expected goals.

2) Quantity. Represents the amount generated, for example, the amount of rupiah, units, and cycles of activities carried out.

3) Timeliness. Is the extent to which an activity is completed at the desired time, taking into account the coordination of other outputs and the time available for other people's activities.

4) Cost-effectiveness. This is the degree to which the use of organizational resources (human, financial, technological, and material) is maximized to achieve the highest yield or reduction in losses from each unit of resource use.

5) Need for supervision. Is the extent to which a worker can carry out a work function without requiring the supervision of a supervisor to prevent undesirable actions.

6) Interpersonal impact. This is the extent to which the employee maintains self-esteem, good name, and cooperation between coworkers and subordinates.

There are several elements that can be used as indicators in assessing the performance of an employee, namely, (Mathis and Jackson; 2009): (a) Quantity of results; (b) Quality of results; (c) Timeliness of results; (d) Presence; (e) Communication works together

\section{Compensation}

Compensation is one of the important functions in human resource management (HRM). Because compensation is one of the most sensitive aspects of work relations. Cases that occur in employment relationships contain compensation issues and various related aspects, such as benefits, compensation increases, compensation structures, and compensation scale (Sutrisno, 2009).

Hasibuan (2006) states, compensation is all income in the form of money, direct or indirect goods received by employees as a reward given by the company. Meanwhile, according to Rivai (2011), "Compensation is something that is received by employees as a substitute for the contribution of their services to the company." Giving compensation is one of the implementations of the function of human resources associated with all types of individual awards as an exchange in carrying out organizational tasks.

\section{Purpose of Compensation}

Providing compensation has positive goals. Opinions of experts about the purpose of giving various kinds of compensation, but in principle the same. The purpose of compensation according to Hasibuan (2006) is as follows:

1) Partnership Collaboration. With compensation, there is a formal partnership between the employer and the employee. Employees must do their duties properly, while employers must pay compensation in accordance with the agreed agreement.

2) Job satisfaction. With payback, employees will be able to meet their physical, social status, and selfish needs so that they get job satisfaction from their positions.

3) Effective Procurement. If the compensation program is set large enough, the procurement of qualified employees for the company will be easier. 
4) Motivation. If the services provided are large enough, the manager will easily motivate his subordinates.

5) Employee Stability. With a compensation program based on fair and proper principles and competitive external consistency, employee stability is guaranteed because turnover is relatively small.

6) Discipline. By providing substantial rewards, employee discipline is getting better. They will realize and obey the rules that apply.

7) Labor Union Influences. With a good compensation program, union influence can be avoided and employees will concentrate on their work.

8) Government Influence. If the compensation program complies with applicable labor laws (such as minimum wage limits), government intervention can be avoided.

\section{Compensation Type}

Compensation is the main reason why most people look for work, according to Rivai (2011) compensation consists of (1) financial compensation; (2) Direct compensation, consisting of payment of employees in the form of wages, salaries, bonuses or commissions; (3) Indirect compensation or benefits, consisting of all payments that do not include direct financial compensation that includes holidays, various kinds of insurance, services such as child care or religious care, and so on. (4) Non-financial Compensation. Non-financial rewards such as praise, self-respect, and recognition of money can affect employee work motivation, productivity, and satisfaction.

The indicators of compensation according to Hasibuan in Novianto and Yuniati (2015) are: (a) Salary, (b) Incentive wages, (c) Bonuses, (d) Insurance, (e) Office Facilities, (f) Benefits.

\section{Work Environment}

The work environment is the overall tools and materials faced, the surrounding environment in which a person works, his work methods, and his work arrangements both as individuals and as a group (Sedarmayanti in Novianto and Yuniati, 2015). The conditions and atmosphere of a good work environment will be created by the organization arrangement that is good and right as well as is produced especially in a well-organized organization.

\section{Type of Work Environment}

According to Sedarmayanti (2001) states that in outline, the type of work environment is divided into 2 namely:

A) Physical Work Environment. The physical work environment is all physical conditions that exist around the workplace that can affect employees both directly and indirectly

The physical work environment factors are as follows:

1) Coloring. Color problems can affect employees in carrying out work, but many companies do not pay attention to color issues. Thus the arrangement should provide benefits, so as to increase employee morale. Staining on the walls of the workspace should use soft colors.

2) Lighting. Information in the workspace of employees plays a very important role in increasing employee morale so that they will be able to show good work results, which means that adequate workplace lighting greatly helps the success of the organization's operational activities.

3) Air. In the workspace of employees needed sufficient air, wherewith the presence of sufficient air exchange, will cause physical fitness of the employee. The temperature is too hot will reduce employee morale in carrying out work. 
4) Noise. Sounds that can be very disturbing employees at work. The noise can damage the work concentration of employees so that employee performance can not be optimal. Therefore, every organization must always try to eliminate the noise or at least suppress it to reduce the noise. The ability of organizations in providing funds for the purpose of noise control is also one of the factors that determine the choice of how to control noise in an organization.

5) Motion Room. An organization should employees who work have enough space to carry out work or tasks. Employees may not be able to work calmly and optimally if the available places cannot provide comfort. Thus space for employees to work should be planned in advance so that employees are not disrupted in carrying out work besides that the company must be able to avoid waste and reduce the cost of a lot of expenses.

6) Security. The sense of security for employees is very influential in employee morale and employee performance. Here what is meant by security is the security that can be put into a physical work environment. If the workplace is not safe the employee will become agitated, unable to concentrate on his work, and employee morale will decrease. Therefore, an organization should continue to strive to create and maintain a safe situation and atmosphere so that employees feel happy and comfortable at work.

7) Cleanliness. A clean work environment will create a healthy environment. Therefore, every organization should always maintain a clean working environment. With a clean environment, employees will feel happy so that employee performance will improve.

\section{B) Non-Physical Work Environment}

The non-physical work environment is all conditions that occur related to work relationships, both relationships with superiors and relationships with subordinates of fellow colleagues, or relationships with subordinates (Sedamayanti, 2001). This non-physical work environment is no less important than the physical work environment. Employee morale is greatly influenced by non-physical work environment conditions, such as relationships with fellow employees and with their leaders. If an employee's relationship with other employees and with the leader runs very well it will be able to make employees feel more comfortable in their work environment. That way employee morale will increase and performance will also increase.

There are five aspects of the non-physical work environment that can affect employee behavior, namely:

1) Work structure, i.e. the extent to which the work given to him has good work and organizational structure.

2) Work responsibilities, i.e. the extent to which workers feel that work understands their responsibilities and is responsible for their actions.

3) Attention and support of leaders, namely the extent to which employees feel that leaders often provide direction, confidence, attention, and respect for them.

4) Cooperation between groups, namely the extent to which employees feel there is good cooperation between existing workgroups.

5) Smooth communication, i.e. the extent to which employees feel that there is good, open, and smooth communication, both between coworkers or with the leadership.

Both can not be separated just like that. Sometimes organizations only prioritize one type of work environment above, but it would be even better if both were implemented to the fullest. That way employee performance can be more leverage. 


\section{Conceptual Framework}

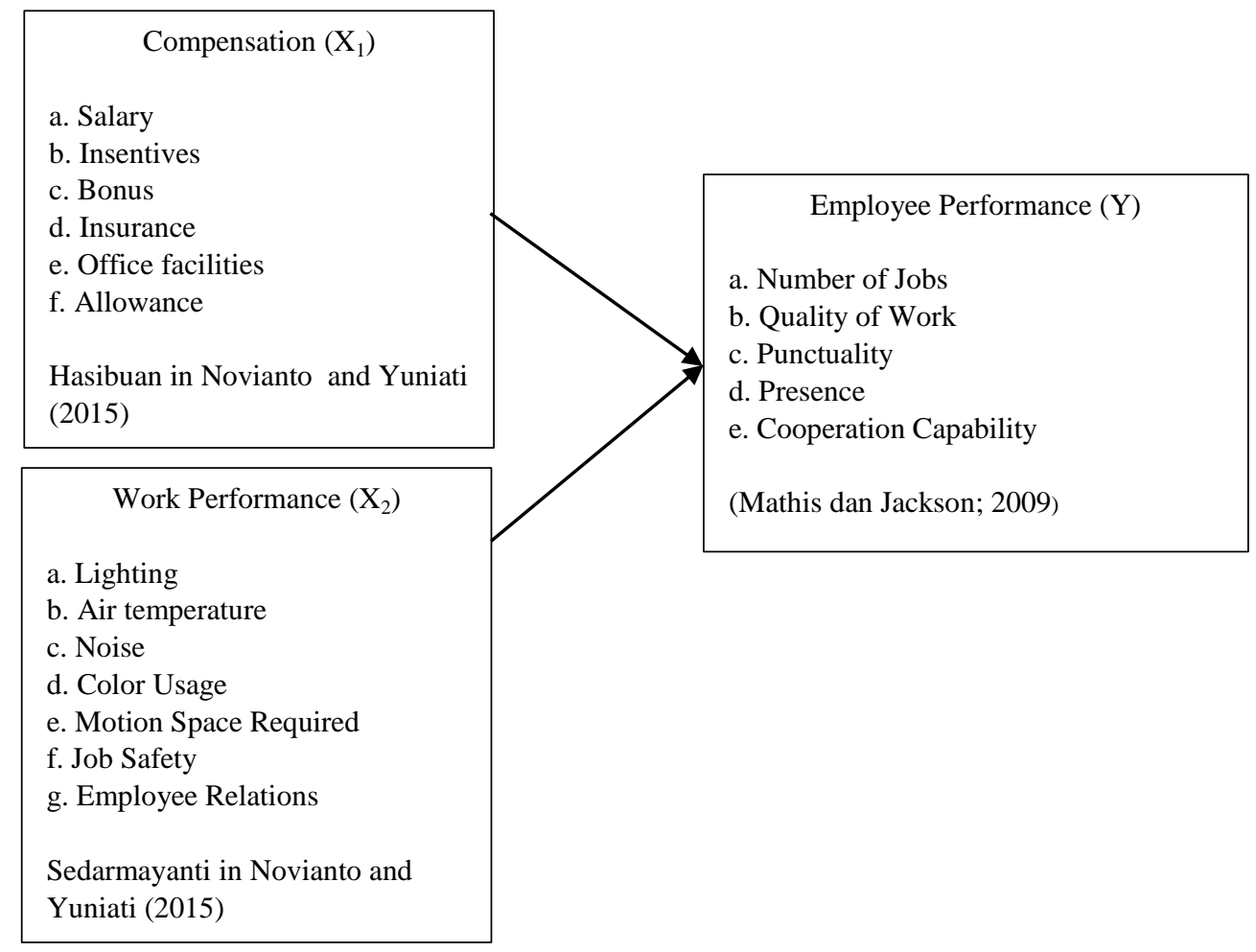

Figure 1. Conceptual Framework

Referring to the purpose of the research to be carried out, as stated in the research objectives mentioned above, which are based on theoretical studies and also from the basic research previously mentioned above, the following framework for this research:

\section{Research Hypothesis}

The hypothesis is a temporary answer to the formulation of the problem that is still presumptive because it still has to be proven and the hypothesis in this study:

$\mathrm{H}_{1}$ : Compensation has a positive effect on employee performance.

$\mathrm{H}_{2}$ : Work Environment has a positive effect on employee performance.

\section{RESEARCH METHODS}

\section{Place of Research}

This research was conducted at the company PT. ASS having its address in Jakarta.

\section{Research design}

The research design used in this study is causal research design. Causal design is useful for measuring the relationships between research variables or is useful for analyzing how a variable affects other variables (Umar, 2013).

\section{Variable Definition and Operationalization}

The definition of this research is:

1. Employee performance is the performance achievement or work results both in quality and quantity achieved by the employees of a time period in carrying out their work duties in accordance with the responsibilities given to employees of PT. ASS. 
2. Compensation is all income in the form of money, direct or indirect goods received by employees in return given by the company PT. ASS.

3. The work environment is the whole of the tools and materials faced, the surrounding environment in which a person works, the working methods, as well as the work arrangements both as individuals and as a group.

Table 1. Definition and operationalization of the Compensation variable

\begin{tabular}{|l|l|c|}
\hline \multicolumn{1}{|c|}{ Variables } & \multicolumn{1}{|c|}{ Indicators } & \multicolumn{1}{|c}{ Scale } \\
\hline \multirow{4}{*}{ Compensation $\left(\mathrm{X}_{1}\right)$} & Salary & \multirow{4}{*}{ Likert (1-5) } \\
& Insentives & \\
\cline { 2 - 2 } & Bonus & \\
\cline { 2 - 2 } & Insurance & \\
\cline { 2 - 2 } & Office facilities & \\
\cline { 2 - 2 } & Allowance & \\
\hline
\end{tabular}

Source: Hasibuan in Novianto and Yuniati (2015)

Table 2. Definition and operationalization of Work Environment variables

\begin{tabular}{|l|l|l|}
\hline \multicolumn{1}{|c|}{ Variables } & \multicolumn{1}{|c|}{ Indicators } & \multicolumn{1}{|c}{ Scale } \\
\hline \multirow{4}{*}{ Work Environment $\left(\mathrm{X}_{2}\right)$} & Lighting & \\
\cline { 2 - 2 } & Air temperature & \multirow{4}{*}{ Likert (1-5) } \\
\cline { 2 - 2 } & Noise & \\
\cline { 2 - 2 } & Color Usage & \\
\cline { 2 - 2 } & Motion Space Required & \\
\cline { 2 - 2 } & Job Safety & \\
\cline { 2 - 2 } & Employee Relations & \\
\hline
\end{tabular}

Source: Sedarmayanti in Novianto and Yuniati (2015)

Table 3. Definisi dan operasionalisasi variabel Kinerja

\begin{tabular}{|c|l|c|}
\hline \multirow{2}{*}{ Variables } & \multicolumn{1}{|c|}{ Indicators } & \multirow{2}{*}{ Scale } \\
\hline \multirow{4}{*}{$\begin{array}{c}\text { Employee } \\
\text { Performance (Y) }\end{array}$} & Number of Jobs & \multirow{4}{*}{ Likert (1-5) } \\
\cline { 2 - 2 } & Quality of Work & \\
\cline { 2 - 2 } & Punctuality & \\
\cline { 2 - 2 } & Presence & \\
\cline { 2 - 2 } & Cooperation Capability & \\
\hline
\end{tabular}

Source: Mathis \& Jackson (2009)

\section{Population and Research Samples}

The population is a generalization area that consists of: objects/subjects that have certain qualities and characteristics determined by researchers to be studied and then drawn conclusions (Sugiyono, 2013). In this study, what is meant by the population is all employees of PT ASS. Whereas what is meant by the sample is part of the number and characteristics possessed by the population (Sugiyono, 2013). In this study, the so-called research sample is all employees of PT ASS where the sampling method using the Saturated sample technique is that the entire population is sampled as many as 43 people. 


\section{Data collection technique}

Data collection techniques in this study were conducted by conducting a questionnaire. In this questionnaire, a closed question model will be used, namely questions that have been accompanied by alternative answers before, so that respondents can choose one of the alternative answers.

\section{Analysis Method}

Data analysis methods that will be used by the author in analyzing data using the SPSS program with the following stages:

\section{a. Descriptive Analysis}

Descriptive analysis is a statistic used to analyze data by describing data that has been collected as it is without intending to make conclusions that apply to the public or generalization (Sugiyono, 2013).

\section{b. Data Quality Test \\ 1. Test Validity}

Validity test is done to measure the validity or validity of a questionnaire. Measuring validity can be done by correlating the scores of question items by comparing the value of $r$ arithmetic with $r$ tables for degree of freedom $(\mathrm{df})=\mathrm{n}-2$, where $(\mathrm{n})$ is the number of research samples. If $\mathrm{r}$ arithmetic> $\mathrm{r}$ table and a positive value then the item or question or indicator is declared valid (Ghozali, 2009).

\section{Reliability Test}

A reliability test is a tool used to measure the consistency of the questionnaire which is an indicator of a variable or construct. A construct. A constructor variable is declared reliable if the Cronbach Alpha value> 0.60 (Ghozali, 2009).

\section{c. Classic assumption test}

\section{Normality Test}

The normality test aims to test whether in the regression model, the dependent and independent variables both have normal distributions or not. The classic assumption test for normality uses the Kolmogorov-Smirnov test, with this test data can be known to use normally distributed or not. If asump. sig. (2-tailed) $>0.05$, then the data is normally distributed and vice versa. (Santoso, 2002).

\section{Multicollinearity Test}

Multicollinearity test aims to test whether there is a correlation between independent variables (independent). A good model should not occur between the independent variables. Detection of the presence or absence of multicollinearity, namely by analyzing tolerance values and Variance Inflation Factors (VIF) <10 and tolerance values> 0.1 (Ghozali, 2009).

\section{Heteroscedasticity Test}

The heteroscedasticity test is to test whether in the regression model there is an unequal variance from the residuals of one observation to another. If the variance from one observation residual to another observation is fixed, then it is called homoscedasticity and if the variance is different it is called heteroscedasticity. A good regression model is a homoscedasticity or heteroscedasticity does not occur (Ghozali, 2009). 


\section{d. Multiple Linear Regression Analysis Test}

Multiple linear regression analysis is used to determine the effect caused by the independent variable indicators of the dependent variable with the following formulation (Sugiyono, 2013):

$$
\mathrm{Y}=\mathrm{a}+\mathrm{b}_{1} \mathrm{X}_{1}+\mathrm{b}_{2} \mathrm{X}_{2}+\mathrm{e}
$$

\section{a. Hypothesis testing}

1. Determination Coefficient Test $\left(\mathrm{R}^{2}\right)$

This test aims to find out how much the ability of the independent variables to explain the dependent variable by looking at the magnitude of the coefficient of total determination $\left(\mathrm{R}^{2}\right)$. A value close to one means that the independent variables provide almost all the information needed to predict variations in the dependent variable (Ghozali, 2009).

\section{b. Statistical Test t}

Statistical test $\mathrm{t}$ is a test to find out how far the influence of one independent variable individually in explaining the variation of the dependent variable. According to Priyatno (2014), the basis for decision making can be done by looking at the probability of its significance, namely:

1) If the probability of significance $>0.05$ then Ho is accepted and $\mathrm{Ha}$ is rejected.

2) If the significance probability is $<0.05$ then Ho is rejected and Ha is accepted.

\section{RESULTS AND DISCUSSION}

1. Characteristics of Respondents. Characteristics of respondents in this study were measured by gender, age, last education, length of work, and salary.

2. Data Quality Test Results

a. Validity Test Results

Table 4. Test Results of the Validity of the Compensation variable

\begin{tabular}{ccccc}
\hline Variables & $\mathrm{R}_{\text {count }}$ & $>$ or & $\mathrm{R}_{\text {table }}$ & Description \\
\hline $\mathrm{X}_{1} \_1$ & $-0,029$ & $<$ & 0,361 & Invalid \\
$\mathrm{X}_{1} \_2$ & 0,655 & $>$ & 0,361 & Valid \\
$\mathrm{X}_{1} \_3$ & 0,589 & $>$ & 0,361 & Valid \\
$\mathrm{X}_{1}{ }_{4}$ & 0,781 & $>$ & 0,361 & Valid \\
$\mathrm{X}_{1}$ 5 & 0,661 & $>$ & 0,361 & Valid \\
$\mathrm{X}_{1} 6$ & 0,570 & $>$ & 0,361 & Valid \\
\hline
\end{tabular}

Source: SPSS Output Results

Table 5. Test Results of Work Environment Validity

\begin{tabular}{ccccc}
\hline Variables & $\mathrm{R}_{\text {count }}$ & $>$ or $<$ & $\mathrm{R}_{\text {table }}$ & Description \\
\hline $\mathrm{X}_{2} \_1$ & 0,724 & $>$ & 0,361 & Valid \\
$\mathrm{X}_{2} \_2$ & 0,475 & $>$ & 0,361 & Valid \\
$\mathrm{X}_{2} \_3$ & 0,583 & $>$ & 0,361 & Valid \\
$\mathrm{X}_{2} \_4$ & 0,567 & $>$ & 0,361 & Valid \\
$\mathrm{X}_{2} \_5$ & $-0,170$ & $<$ & 0,361 & Invalid \\
$\mathrm{X}_{2}$ 6 & 0,797 & $>$ & 0,361 & Valid \\
$\mathrm{X}_{2}$ 7 & 0,680 & $>$ & 0,361 & Valid \\
\hline
\end{tabular}

Source: SPSS Output Results 
Table 6. Validity Test Results of Performance variables

\begin{tabular}{ccccc}
\hline Variables & $\mathrm{R}_{\text {count }}$ & $>$ or & $\mathrm{R}_{\text {table }}$ & Description \\
\hline Y_1 & 0,457 & $>$ & 0,361 & Valid \\
Y_2 & 0,817 & $>$ & 0,361 & Valid \\
Y_3 & 0,495 & $>$ & 0,361 & Valid \\
Y_4 & 0,711 & $>$ & 0,361 & Valid \\
Y_5 & 0,683 & $<$ & 0,361 & Valid \\
\hline
\end{tabular}

Source: SPSS Output Results

a. Reliability Test Results

Table 7. Reliability Test Results

\begin{tabular}{lccc}
\hline \multicolumn{1}{c}{ Variables } & $\mathrm{r} \alpha_{\text {table }}$ & $\mathrm{r} \alpha_{\text {t-count }}$ & Description \\
\hline 1. Compensation & 0,6 & 0,843 & Reliable \\
2. Work Enviroment & 0,6 & 0,848 & Reliable \\
3. Employee Performance & 0,6 & 0,827 & Reliable \\
\hline
\end{tabular}

Source: SPSS Output Results

4. Classic Assumption Test Results

a. Normality Test Results

Table 8. Normality Test

One-Sample Kolmogorov-Smirnov Test

\begin{tabular}{lll}
\hline & & $\begin{array}{l}\text { Unstandardized Predicted } \\
\text { Value }\end{array}$ \\
\hline $\mathrm{N}$ & & 43 \\
Normal Parameters $^{\mathrm{a}, \mathrm{b}}$ & Mean & 19.6000000 \\
& Std. Deviation & 2.83933466 \\
Most Extreme Differences & Absolute & .114 \\
& Positive & .110 \\
& Negative & -.114 \\
Test Statistic & & .114 \\
Asymp. Sig. (2-tailed) & & $.200^{\mathrm{c}, \mathrm{d}}$ \\
\hline
\end{tabular}

a. Test distribution is Normal.b. Calculated from data.

a. Multicollinearity Test Results

Table 9. Multicollinearity Test

\begin{tabular}{|c|c|c|c|}
\hline Variabel & Tolerance & VIF & Keterangan \\
\hline $\begin{array}{c}\text { Kompensasi } \\
\left(\mathrm{X}_{1}\right)\end{array}$ & 0,978 & 1,022 & $\begin{array}{c}\text { Bebas } \\
\text { Multikolinieritas }\end{array}$ \\
\hline $\begin{array}{c}\text { Lingkungan } \\
\text { Kerja }\left(\mathrm{X}_{2}\right)\end{array}$ & 0,978 & 1,022 & $\begin{array}{c}\text { Bebas } \\
\text { Multikolinieritas }\end{array}$ \\
\hline
\end{tabular}


c. Heteroscedasticity Test Results

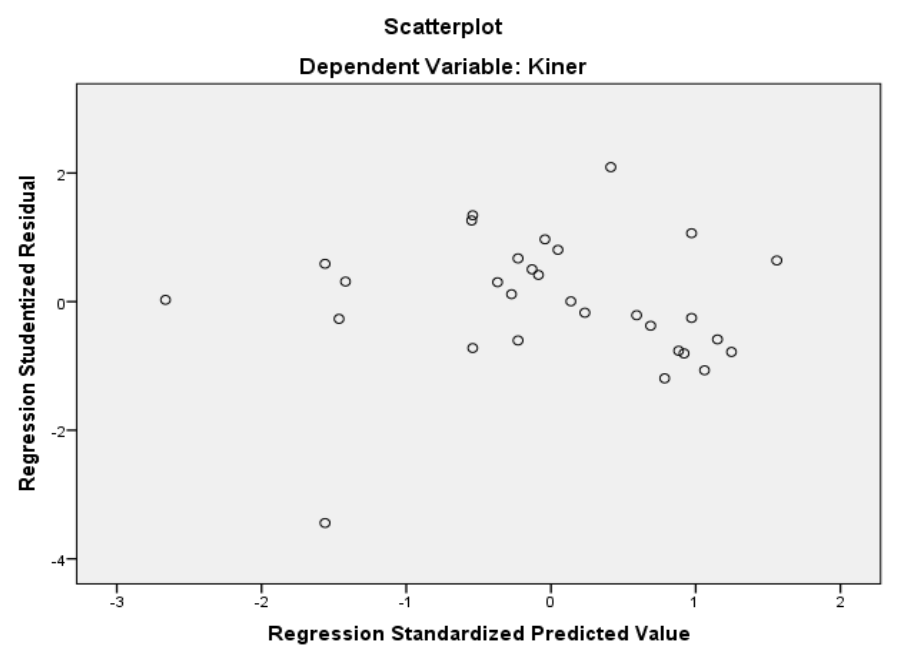

Figure 2. Heteroscedasticity Test

5. Test Results of Multiple Linear Regression Analysis

Table 10. Test Analysis of Multiple Linear Regression

\begin{tabular}{llrrr}
\hline & & \multicolumn{2}{c}{$\begin{array}{c}\text { Unstandardized } \\
\text { Coefficients }\end{array}$} & \multicolumn{2}{c}{$\begin{array}{c}\text { Standardized } \\
\text { Coefficients }\end{array}$} \\
\cline { 2 - 5 } Model & \multicolumn{1}{c}{ B } & Std. Error & \multicolumn{2}{c}{ Beta } \\
\hline 1 (Constant) & 3.082 & 2.516 & \\
& Kompensasi & -.128 & .098 & -.121 \\
& Lingkungan Kerja & .790 & .082 & .890 \\
\hline
\end{tabular}

6. Hypothesis Test Results

a. Determination Coefficient Test Results $\left(\mathrm{R}^{2}\right)$

Tabel 11. Determination Coefficient Test Results $\left(\mathrm{R}^{2}\right)$

Model Summary ${ }^{\mathrm{b}}$

\begin{tabular}{lcccc}
\hline Model & $\mathrm{R}$ & $\mathrm{R}$ Square & $\begin{array}{c}\text { Adjusted R } \\
\text { Square }\end{array}$ & $\begin{array}{c}\text { Std. Error of the } \\
\text { Estimate }\end{array}$ \\
\hline 1 & $.881^{\mathrm{a}}$ & .776 & .759 & 1.598 \\
\hline a. Predictors: (Constant), Lingkungan Kerja, Kompensasi & & \\
b. Dependent Variable: Kinerja Karyawan & &
\end{tabular}

b. Statistical Test Results $\mathrm{t}$

\begin{tabular}{lllll}
\hline Variables & $\mathrm{T}_{\text {count }}$ & $\mathrm{Sig}$ & $(\alpha)$ & Description \\
\hline Compensation & -1.314 & 0.200 & 0.05 & No effect \\
Work Environment & 9.66 & 0.000 & 0.05 & Influential \\
\hline
\end{tabular}

\section{Discussion}

The results of the first research hypothesis showed that compensation did not significantly influence the performance of the employees of PT Reliable Software Prosperous. This research is in line with the results, compensation has no significant effect on employee performance (Juniarti, 2014). There is no significant direct effect between compensation on employee performance, (Rismawati, 2016) and (Tulenan, 2015). These results are not in line with the research of Alfiyah and Riyanto (2019) with the results that 
there is a positive and significant effect between compensation for Employee Performance at the LP3I Poliktenik Jakarta. Compensation and work environment partially have a positive effect on job satisfaction and employee performance, (Permadi, et al., 2018). Compensation has a positive impact on employee performance, (Hameed, et al., 2014), and (Njoroge and Kwasira, 2015), (Siddiqi and Tangem, 2108).

The results of the study that the work environment has a significant effect on the performance of employees of PT. Reliable Software Prosperous. The results are in line with Narasuci et al., (2018) there is a positive and significant influence of the work environment on lecturer performance. There is an influence between the work environment and employee performance, (Darma and Supriyanto, 2017). (Malik et all., 2011). The results of this study are not in line with the Work Environment does not have a significant effect on Employee Performance at CV Roda Jati Karanganyar, (Rukmini, 2017). The indirect effect of the work environment on job satisfaction through employee performance, obtained significant results (Riansariy, et all., 2012). Work environment conditions that have negative impact on job performance (Al-Omari and Okasheh, 2017).

\section{CONCLUSION}

Based on the results of the analysis and processing of data that has been done and explained in the previous chapter, the authors draw conclusions from this study: (1) The results showed that compensation did not significantly influence the performance of PT ASS employees; (2) The results of the study that the work environment has a significant effect on the performance of employees of PT ASS.

\section{Suggestion}

For suggestions that the author can give so that further research becomes sharper and also suggestions for input to PT ASS, as follows:

1. In subsequent studies in order to be able to add other variables that can affect the performance of employees not examined in this study for example leadership, organizational culture and training and others. So that it can strengthen the research results obtained. Each company has a different personal character, so the company that is the object of research should the research statement is given must be in accordance with the needs and conditions of the company. And also the filling out of the questionnaire must be strictly monitored so that there are no blank answers or wrong answers.

2. The company needs to pay attention to giving employee rights, commitments when paying employee salaries on time and there is overtime pay for those who do work beyond the time they should be satisfied with the compensation given by the company.

3. The environment significantly influences employee performance. Therefore the company needs to provide a comfortable work environment with adequate facilities, good air circulation, good lighting, work safety guarantees, and expansion of the workspace so that employees have sufficient space in carrying out work activities.

\section{REFERENCES}

Alfiyah, N. and Riyanto, S. (2019). The Effect of Compensation, Work Environment and Training on Employees' Performance of Politeknik LP3I Jakarta. IJISRT, 4 (5), 947955.

Al-Omari, K., H, Okasheh., (2017). The Influence of Work Environment on Job Performance: A Case Study of Engineering Company in Jordan. IJAES, 12 (24), 544550. 
Darma, P.S. and Supriyanto, A.S. (2017). The Effect of Compensation on Satisfaction and Employee Performance. MEC-J, 1 (1), 69-78.

Ghozali, Imam. (2009). Aplikasi Analisis Multivariate dengan Program SPSS. Semarang. Badan Penerbit UNDIP.

Hameed, A., Ramzan, M., Zubair, H. M. K., Ali, G. \& Arslan, M. (2014). Impact of Compensation on Employee Performance (Empirical Evidence from Banking Sector of Pakistan). International Journal of Business and Social Science. 5(2);302-309.

Hasibuan, Malayu, S.P., (2006). Manajemen Sumber Daya Manusia, Edisi Cetakan Kesembilan, PT. Bumi Aksara, Jakarta.

Juniarti, D. (2014). "Pengaruh Kompensasi Terhadap Kinerja Karyawan dengan Motivasi kerja sebagai Variabel Mediating pada Karyawan Perbankan Bagian Keuangan di Tanjungpinang”, dalam http://jurnal.umrah.ac.id/wpcontent/uploads/gravity_forms /1ec61c9cb232a03a96d0947c6478e525e/2014/05/JURNAL-DARFINA-JUNIARTI090462201065-AKUNTANSI2014.pdf.

Malik, M. I., Ahmad, A., Gomez, S. F., \& Ali, M. (2011). A Study of Work Environment and Employees' Performance in Pakistan. African Journal of Business Management, 5(34).

Mangkunegara, A.A.Anwar Prabu. 2009. Manajemen Sumber Daya Manusia, Penerbit PT Remaja Rosdakarya, Jakarta.

Mathis, Robert L. and Jackson, John H. (2009). Human Resource Management, Sumber Daya Manusia,Edisi 10, Penerbit: Salemba Empat, Jakarta.

Narasuci.W., Setiawan. M. and Noermijati. (2018). Effect Of Work Environment On Lecturer Performance Mediated By Work Motivation and Job Satisfaction. Journal of Applied Management, 16 (4), 645-653.

Njoroge, S.W. and Kwasira, J. (2015). Influence of Compensation and Reward on Performance of Employees at Nakuru County Government. IOSR-JBM, 17 (11), 87-93.

Novianto, D., \& Yuniati, T. (2015). Pengaruh Kompensasi dan Lingkungan Kerja Terhadap Kepuasan Kerja PT. Galang Kreasi Sempurna. Jurnal Ilmu dan Riset Manajemen, 4(6), 3-4.

Permadi, K.O., Landra, N., Kusuma, I.G.A.E.T., and Sudja, I.N. (2018). The Impact Of Compensation And Work Environment Towards Job Satisfaction To Affect The Employee Performances. IJMCI, 6 (2), 1248-1258.

Priyatno, Duwi. (2014). SPSS 22: Pengolah Data Terprakatis. Yogyakarta. CV. Andi Offset.

Riansari, T., Sudiro, A., \& Rofiaty. (2012). Pengaruh Kompensasi dan Lingkungan Kerja terhadap Kepuasan Kerja dan Kinerja Karyawan. Jurnal Aplikasi Manajemen, 10 (4), 811-820.

Rismawati. (2016). The Effect of Working Environment, Compensation and Working Ethos Towards Employee Performance on Mariso Districtes Office In Makassar. IJSTR, 5 (8), 48-51.

Rivai, Veithzal. (2011). Manajemen Sumber Daya Manusia Untuk Perusahaan, Dari Teori Ke Praktik, Edisi Kedua, Penerbit: RAJAWALI PERS PT.Rajagrafindo Persada, Jakarta.

Rukmini. (2017). Pengaruh Kompensasi dan Lingkungan Kerja Terhadap Kinerja Karyawan pada CV. Roda Jati Karanganyar. Jurnal Akuntansi dan Pajak, 17 (02), 49-60.

Santoso, Singgih. (2002). Statistik Parametrik. Cetakan ketiga. Jakarta. PT. Gramedia Pustaka Utama.

Sedamayanti. (2001). Sumber Daya Manusia dan Produktivitas Kerja. Jakarta. Mandar Maju. Siddiqi, T. and Tangem, S. (2018). Impact of Work Environment, Compensation and Motivation on The Performance of Employees In The Insurance Companies of Bangladesh. SEAJCB Economics and Law, 15 (5), 153-162.

Sugiyono. (2013). Metode Penelitian Bisnis. Bandung. Alfabeta. 
Sunyoto, Danang. (2015). Penelitian Sumber Daya Manusia. Yogyakarta. CAPS (Canter of Sutrisno, Edy. (2009). Manajemen Sumber Dana Manusia. Jakarta. Kencana

Sutrisno, Edy. (2010). Budaya Organisasi, Edisi Pertama, Cetakan Ke-1, Penerbit Kencana, Jakarta.

Tulenan, S. (2015). The Effect of Work Environment and Compensation Toward Employee Performance At the Office of State Assets and Auction Service Manado. Jurnal Riset Ekonomi, Manajemen, Bisnis Dan Akuntansi, 3(3), 672-682.

Umar, Husein. (2013). Desain Penelitian MSDM dan Perilaku Karyawan Paradigma Positivistik dan Berbasis Pemecahan Masalah. Jakarta. PT Raja Grafindo Persada. 